This is the pre-peer reviewed version of the following article: 'Assessing the Field of Science and Religion: Advice From the Next Generation', which has been published in final form at http://rdcu.be/vew $Q$. This article may be used for non-commercial purposes in accordance with Wiley Terms and Conditions for Self-Archiving.

\title{
Diagnosing the Field of Science and Religion: Advice from the Next Generation
}

\section{Michael S. Burdett}

The field of science and religion is undergoing a transition today requiring diagnosis of its past movements and identifying its future trajectories. Seasoned leaders that have made up the defining voices for decades have retired or are retiring imminently: Wentzel van Huyssteen, John Polkinghorne, John Hedley Brooke, Denis Alexander, Philip Hefner, Ted Peters and Fraser Watts. This has left open major academic chairs in science and religion that have been recently filled or are to be filled in the impending future. What is more, there has been recent turnover with the Andreas Idreos Professorship at Oxford leading to a resurrected master's degree in science and religion along with burgeoning graduate degrees in science and religion at e.g. the University of Edinburgh. Science and religion societies also feel this sea change. The theme for the United Kingdom's Science and Religion Forum in 2015 was a celebration of the societies 40 year anniversary (originally established by Arthur Peacocke) entitled "Science and Religion: Celebrating the Dialogue and Exploring the Future". David Wilkinson, Alister McGrath, John Hedley-Brooke and Wim Drees were invited to reflect on the field the last half century and where they think it might be going. Indeed, even the major funder of the field, The John Templeton Foundation, has seen changing leadership recently and even sponsored a seminal event in 2012 at the British Academy entitled "Gifford Lectures Revisited" that had Templeton Prize winners and Gifford Lecturers reflect upon the past and present moments so as to speculate about the future of the field. But, more than this I've had countless conversations the past few years with many scholars and laymen and the sense many of us feel is that science and religion is at an inflection point. Indeed, these private conversations have spilled over into print and in public discourse. Taede Smedes (2008) touches on this precise point when he says “....although the field may have reached a 
state of maturity, it also seems to have reached a kind of midlife crisis." I think all of us feel "stock taking" is needed for the health of the field and because our present moment requires it.

What is more, a voice from the next generation is timely and important. Whilst attempts to summarize the "state-of-play" from established senior science and religion scholars is an obvious and critical move - after all the past for many of these figureheads were actually lived discourse rather than words on a page as they have been for me-it does not eclipse the value of consulting the next generation on what we see have been the most important developments the last half century and where, we hope, it might go. Indeed, the eyes of distance are always critical for the health of any subject, science and religion included. Listening to those of us on the receiving end of this history is an important and needed perspective for the field.

Therefore, in this paper I will add my voice to this growing crowd of commentators. I will give a brief account of the history of the field of science and religion and analyze present issues so as to diagnose future trajectories. To focus my efforts on the past I will turn to Ian Barbour's own stock taking of the field some 40 years ago in an essay entitled 'Science and Religion Today" (Barbour 1968a) before giving some personal comments where I contend that much of the field in the past 40-50 years has traditionally focused on the conversation between Christianity and the natural sciences. At present, however, we are beginning to see that the future of the conversation lies beyond the dialogue between the natural sciences and Christianity. I suggest that the future dialogue will and ought to expand in several directions: (1) into non-Christian religions and theology, (2) into the human sciences, (3) into Science and Technology Studies and (4) into the humanities more broadly.

\section{The Ghost of Science and Religion Past}


It is almost uncontested that the late Ian Barbour is attributed with the founding of the academic study of science and religion. His seminal book Issues in Science and Religion (Barbour 1966) solidified this area of study and secured his position as the patron saint of it (Smedes 2008, 235-6). The book itself is still one of the most important introductions to the field, if not a little dated in places, and every time I open its pages I am stunned by its balance, coherence and comprehension. Some two years later Barbour edited a sister volume entitled Science \& Religion: New Perspectives on the Dialogue (Barbour 1968b). His chapter contribution in it, entitled "Science and Religion Today", provides an instructive counterpoint to us for in it we glimpse what concerns were at the forefront of the field at its origin. So, allow me to unpack this article by way of shining light on the "past" field of science and religion and what leaders of the field thought about science and religion at its origin.

\section{Barbour's Assessment at the Origin of the Field of Science and Religion}

Barbour begins the essay be acknowledging that much of the field at its origin was concerned with not repeating the conflicts of the past. In particular, Barbour cites three areas where conflict had arisen for science and religion but, by and large, were no longer issues for the field.

First, Barbour points to the volatility and conflict associated with scriptural literalism. Whereas scriptural hermeneutics proved to be an important topic in such seminal science and religion historical events as the condemnation of Galileo and in the reception of Darwin's theory of evolution, Barbour claimed in the late 1960's that the field of science and religion had moved beyond the impasse of scriptural literalism and scientific enquiry. As Barbour (1968a, 5) put it "The authors in the present volume see in Genesis the images of a prescientific cosmology used to express abiding religious insights. Scriptural literalism is no 
longer a major issue between science and religion." And yet, some 40 years later an entire museum in Kentucky would be built as a symbolic edifice to scriptural literalism and the continued battle between science and religion. Indeed, Barbour $(2008,266)$ himself would later say "I under-estimated the appeal of creationism and the new forms it would take in public education after losing repeated challenges in the courts."

Second, Barbour insists that the "God of the gaps" strategy within the science and religion engagement had run its course. The examples of history caution such a move. The Newtonian God who had to periodically intervene to re-align planetary deviations was removed a century later by Laplace's calculations. Similarly, the God who created the eye by divine fiat invoked by certain $18^{\text {th }}$ century scientists was made superfluous by Darwin's theory of evolution. Barbour claimed that direct "intervention" into the natural world was no longer en vogue for the field of science and religion. Yes, special divine action was an important topic (and would become a central issue in the 1980's to the present) but noninterventionist approaches were favored. Thus, Barbour (1968a, 6) happily claimed "the 'God of the gaps' is rejected by most theologians as well as scientists today." Yet many argue the Intelligent Design movement today has once again resurrected this whipping boy of the science and religion dialogue. Indeed, Barbour $(2001,211)$ would go on to criticize Intelligent Design for invoking this science and religion heresy.

Finally, Barbour cites the demise of both evolutionary naturalism and natural theology. Barbour argues that there are still proponents of naturalism but that this is not a conclusion warranted by scientific findings but rather a philosophical/metaphysical position presupposed outside of the domain of science. In the same way, Barbour argues we need to resist the urge to utilize scientific evidence in support of theism. In other words, trying to build a robust theology on purely natural and scientific means, as natural theology had done in the $18^{\text {th }}$ and $19^{\text {th }}$ centuries, was doomed to failure from the beginning. Doing so would only 
ever invite the God of deism, not that of any particular faith tradition, and would lead to God's removal in public life. ${ }^{1}$ As Barbour $(1968 \mathrm{a}, 8)$ claims "Most contemporary Protestant theologians have little interest in natural theology, and most philosophers are dubious about deriving any far-reaching metaphysical conclusions...from scientific theories." However, yet again, we find here that Barbour's contentions about "sorting out" the past conflicts of science and religion are not so clear cut. Metaphysical naturalism still seems to be a constant threat to the field with characters such as Jerry Coyne and Richard Dawkins still, somehow, having a voice in how science and religion is perceived by the surrounding populace. And, we have seen a renewed interest in natural theology by theologians such as Alister McGrath (2008); albeit not the brand that is decried by Barbour. In fact, it is anticipated by him.

Perhaps Barbour's assessment of the field in the late 1960's should act as a cautionary tale to us. As someone whose area of interest in theology is eschatology and futurism, I can personally attest to the short shelf life of any claims about the future. What is more, making bold claims that certain conflicts or issues would be sorted once for all just doesn't take seriously enough the highly contextual nature of these issues. For, when we take the claims of scholars such as David Livingstone seriously ${ }^{2}$ - i.e. that doctrinal adherence or cognitive belief is just one factor in a wide array of influences on how an issue in science and religion takes hold-we ought to be more reticent that pure argument alone can sort out anything for good in this field.

Past conflicts were not the greatest threat to the field of science and religion, Barbour thought. Rather, in the 1960's he found a much larger threat to the dialogue in the form of various arguments for their independence-i.e. the Gouldian non-overlapping magisteria (Gould 1999). Several movements promulgated the separation of science and religion, the two most significant Barbour identifies were neo-orthodoxy and existentialism. Neoorthodoxy challenged the theological contention that anything of real value could be gained 
from studying "the book of nature". Instead, all knowledge of God had to be grounded in the special self-revelation of God in Christ and adhered to by faith. As Barbour put it "Religious faith depends entirely on the divine initiative, not on discovery of the kind by which science advances" (Barbour 1968a, 9). For the neo-orthodox position, science might fill out the empirical details of particular natural events but the theological import of things like a doctrine of creation is not in the "how" of the natural order but rather is to tell us something of God's nature (that he is sovereign, transcendent and purposeful) and that the world is ordered and largely good (Barbour 1968a, 10-11). Therefore, scientific and theological statements operate on different levels and have differing aims. As Barbour tells us, it is hard to see, then, why science and religion ought to discuss anything if they have no area of common overlap.

Besides a blow to science and religion from within the confines of theology, Barbour also identifies a detractor from within philosophy. Existentialists and those in the I-Thou tradition assert that personal selfhood and interpersonal relationships can only be known in terms of "subjective involvement". There is a special kind of knowledge gained only when one is personally committed and invested in the area of inquiry. Many religious thinkers claim religious knowledge is of this existentialist, self-involved variety. Scientific knowledge, on the other hand, eradicates such knowledge and promotes detachment from its line of inquiry. One cannot be a good scientist by giving subjective accounts of experimental data - it must be reproducible without personal bias. Therefore, any dialogue between science and religion will be foolhardy because they are isolated by method, commitment and aim.

Of course, in this essay Barbour does more than cite past conflicts. He also points out the areas of productive dialogue that he foresaw would define it for the future. In particular, Barbour puts forward two areas of productive dialogue and several more future "prospects for dialogue" he thought required addressing. 
First, several scholars at that time were actually drawing several parallels between the methods of science and religion despite the existentialist and positivist claims to the contrary. The work of philosophers Russell Hanson (1958) and Thomas Kuhn (1970) challenged the positivistic view of science and Michael Polanyi (1962) indicated that personal judgments were endemic to the practice of any science. Hence, separating science and religion by differing methods of concern (i.e. "subjective involvement" vs. "objective distance") just didn't fit the evidence on either side. ${ }^{3}$ Instead, identifying commonalities in method and in operation of respective field was a highly fecund venture that Barbour encouraged greatly.

Second, Barbour points to the productive interaction between evolution and theology. The work of Pierre Teilhard de Chardin (1975) was flying off the shelves in the 1960's across the English-speaking world. His creative and bold synthesis of evolution and the Christian faith was ground-breaking at the time and, despite constantly finding his text's in used bookshops today, he is enjoying something of a minor resurgence. Indeed, Barbour himself seemed to be swept away by the productivity of Teilhard's synthesis for both its broad evolutionary scope and a scientifically-informed theology. Barbour held that projects such as Teilhard's was the shape of things to come.

Barbour became even more speculative when commenting on the many issues raised by others in the book aforementioned. Inasmuch as the other contributions fill-out and help to delineate the field at its origin, Barbour raises five illuminating questions in dialogue with these other scholars. (1) What is the place of nature in theology? (2) Should we seek a unified world-view? (3) Is metaphysics a bridge between science and religion? (4) Is the idea of God's creativity in nature a reversion to the "God of gaps"? (5) Does evolution have implications for our understanding of God? I don't have the space here to unpack all of these questions nor how Barbour approaches them as important trajectories for future research but 
what fascinates me in all these questions is how many of them still drive the field today. We are still trying to work out the proper bounds and place of natural theology and indeed the place of nature within a robust theological framework. We are still grappling with the implications of evolutionary theory for theology and religion. We are still wrestling with the nature of divine action as it relates to natural mechanisms. We are still trying to discern the boundaries of science and religion as they relate to each other and we continually rely upon and hope that philosophy can act as an important handmaiden to addressing many of these questions.

Of course, I'm not saying that nothing of substance has occurred in the field the last half century. Clearly, much has been done in the intervening time to advance our deeper appreciation of these questions and perhaps we understand a bit more about how to begin answering some of them. But these questions remain and it is startling how similar the research programs are today with those just at the origin of the field itself.

\section{My Thoughts on the Past}

Transitioning now from Barbour's perspective on the field at its origin, I'd like to make some comments about what I think has typified it the last $40-50$ years. First, it is clear to me that the natural sciences have dominated the science and religion conversation. Within the physical sciences the following illuminate the kinds of topics broached: (1) Divine action and quantum indeterminacy, (2) the theological implications of Big Bang cosmology and the physical origins of the universe and (3) the far future of the cosmos and its import into eschatology. Or we might turn to representative issues within the life sciences. Things like: (1) apparent directionality or convergence in special trajectories and what this might say about a divine Creator, (2) what paleogenetics might tell us about our mythic primogenitors and (3) how socio-biology through things like kin selection and reciprocal altruism shifts our 
conceptions of evolution and has significant import for theism. The natural sciences seems to be where all the science and religion action has taken place.

I am in good company when I make this claim. In the aforementioned event at the British Academy where previous Templeton Prize winners and Gifford Lecturers were asked to comment on the field in 2012 , the majority made the exact same observation. What is more, as we have seen in Barbour's synopsis of the field, all scientific issues he touched upon were firmly lodged within the natural sciences. I'm sure there are a plethora of explanations for this bias that many more senior than I could hazard to make but, whatever explanation might be given, it is a truism of science and religion's past.

Before turning to the final section of this paper on the present concerns and trajectories latent in the field, it is important to note, briefly, three other features that I believe have characterized the field since its inception. Moving from the biases on the scientific side of this dialogue, we can distinguish something similar on the theology/religion side. Namely, almost all engagement with the sciences in the field have been with Christianity and Christian theology. Of course, the book Science and Religion Around the World (Brooke and Numbers 2011) has invited greater contribution from the other non-Christian faith traditions. But, where this has occurred it is either scant ${ }^{4}$ or it hasn't made its way to the forefront of the field. Finally, I'd like to add that both history and philosophy have been significant areas of discourse in the field of science and religion. Indeed both have acted as an important ballast amidst the forays into the tumultuous and normative waters of engagement between science and religion. Some of the most impressive and timely work relies upon the consistent work done by historians of science and religion such as John Hedley-Brooke (1991), Peter Harrison (2015), David Livingstone (2014) and Ronald Numbers (2009). Philosophers such as Keith Ward (2008), Philip Clayton (2011), Ernan McMullin (1992) and Alvin Plantinga (2011) have equally been robust figures in science and religion providing the conceptual clarity so 
needed to make certain scientists and those that study faith do not talk past one another. So, to summarize, I'd say the past has been typified by, largely, engagement between the natural sciences and Christianity with significant and steady input from historians and philosophers.

\section{The Ghost of Science and Religion Present and Future: Broadening the Boundaries}

In the remaining space I want to both assess current trends in the field that signal a new tack and trajectory and, where no such trend is observable, I also will comment on where I think the field ought to go. I've structured my thoughts around four distinct foci in this regard. (1) Expansion into non-Christian religions and theology; (2) more substantial discourse in the human sciences; (3) greater dialogue with the burgeoning field of Science and Technology Studies and (4) broadening into the humanities more generally.

\section{Expansion into Non-Christian Religions and Theology}

In many ways the recognition that the bulk of the conversation has depended upon a singular religion, Christianity, invites such a call to the rest of the faith traditions. But, beyond just the argument for "playing fair", it is clear that this invitation is critical because non-Christian religions are on the rise. Recent numbers from the Pew Research Center (2015) suggest that Islam is expected to be one of the fastest growing religions in the world the next several decades. From 2010 to 2050 it is expected to grow by $73 \%$ worldwide while the next closest religion, Christianity, will only grow by $35 \%$ during the same period of time. In fact, Islam is the only religion that will spread faster than the world's population as a whole. It is expected that Islam will nearly makeup the same percentage of the world population in 2050 as the current leader Christianity. The expansion of globalization and mobilization the last 50-60 years has meant an increasing exposure to the plurality of differing faiths. Indeed, whereas some 50-60 years ago the standard secularization thesis reigned supreme and we 
were taught that the rest of the world would soon look like Western Europe, it is clear that current global politics and society cannot be explained without reference to the proliferation of religion. ${ }^{5}$

Of course, part of this growing plurality is into minority religions and non-traditional religions or religious faith. This can mean growth of minority religions like Baha'is or, as we see in the USA and elsewhere, the rise of the "Nones" where people increasingly have no faith or decline official affiliation (Pew Research Center 2012). The rapidly changing currents on the religious side of the science and religion field command engagement with these growing religious trends and the faithful who adhere to them explicitly or implicitly.

I should add a few things related to my claims here. First, this doesn't mean utilizing only the tools of religious studies to do so. Yes, studying the phenomenon of religion is an important venture especially with the proliferation of faiths around the world but real substantive work also needs to be done by practitioners, adherents and theologians. Drawing in the work done by comparative theology will be critical to engaging these other faith traditions well.

Second, I signal a similar call to the under-represented theological sub-disciplines in the field. So often scientists who happen to be amidst the faithful lead the dialogue. Frankly, we need more theologians qua theologians in this field. ${ }^{6}$ Traditionally, this has meant employing philosophers of religion as philosophical theologians or, to a lesser extent, constructive theologians. However, historical theology, the study of sacred texts, ethics and political theology, practical and applied theology all can contribute in their own way to the field. For example, new work on the evolution of morality ought to spur us to include theological ethicists. Current research on the science of ritual ought to incite us to call upon practical, historical and liturgical theologians. Even if this work is already being done it is not 
often included within the boundaries of the science and religion field. Hence, it is a key component of this "broadening the boundaries" initiative I am putting forward here.

Finally, increased globalization and mobilization hasn't just meant exposure to other faiths within our own borders but rather an expansion of our faith traditions into other parts of the world. Current research by the Pew Research Center (2011) and from work by Phillip Jenkins (2002) reveals the center of gravity of Christianity is creeping southward. Much could be said about what impact this might have beyond the borders of science and religion but one of the most significant challenges ahead for the field will be the clash between a lauded naturalistic (methodological or metaphysical) paradigm from America and Europe that is so central to the practice of science and the more animistic, spiritualist and holistic paradigm of places like Africa and South America. Work done by Smith and Yong (2010) on science and religion from a Pentecostal and Renewalist vantage point are central to starting this dialogue well and facing it head on. ${ }^{7}$ However, this is just the beginning of the dialogue. More resources need to be poured into it.

\section{More Substantial Discourse in the Human Sciences}

I've referred several times now to the event at the British Academy in London entitled "Gifford Lectures Revisited". All the speakers present were asked to comment not only on their own contribution to the past field of science and religion but how their views of the field have changed and what they might include in the Gifford Lectures were they to give them today. As an attendee I was given the distinct impression that, as I've intimated, the consensus was the past focused on our surrounding natural environment. However, they also overwhelmingly stated that the future of the field lies with the study of ourselves - in the study of the human being. 
Today we are seeing a surge of interest in the human sciences. Whereas human science leaders in the field have been around since the beginning-Malcolm Jeeves, Nancy Murphy or Fraser Watts-it is only in the last 10-15 years where it has begun to take a major position in the field.

Two areas in the human sciences are worth unpacking in more detail: (1) psychology and neuroscience and (2) sociology and anthropology. One area of the scientific study of religion has had significant impact in recent years: the cognitive science of religion. Lead by people such as Stewart Guthrie (1995), Thomas Lawson, Richard Sosis, Justin Barrett (2004), Robert McCauley (2011), Pascal Boyer (2001) and Scott Atran (2002), the study of the development of religion and religious thinking as "maturationally natural" within normal human beings has helped to solidify the fecundity of the human sciences in the field of science and religion. Indeed, we are at the leading edge of identifying the philosophical and theological implications of the findings of the cognitive science of religion and texts by Aku Visala (2011) and Helen De Cruz and John De Smedt (2015) are leading this important conversation.

The second area concerns sociology and anthropology. There have been a proliferation of sociological studies on religious adherents' views of science and scientists' views of faith. Elaine Ecklund (2010) gives an important assessment of top scientists' beliefs about religion, debunking some of the myths in the process like all atheistic scientists are hostile to religion and that spirituality does not matter to scientists. Studies such as Ecklund's are a breath of fresh air in a public space dominated by accusation and misunderstanding. We find something similar in the work of Christian Smith and Jonathan Hill, only now it is the faithful's perception of science that is scrutinized. The work of Jonathan Hill (2014), for example, ascertains what factors influence rejection of science and specifically evolution in North American Christian populations. Hill concludes it has everything to do with one's 
social networks and the inherent ideologies found therein — not home schooling, not level of education and not geography.

What recent sociological studies tell us is that often non-cognitive or extra-cognitive factors can play a tremendous role at the intersection of science and religion. We are seeing an extra-cognitive turn in science and religion where scholars are attending more and more to practice and other embodied factors that help to shape people besides just rational belief. Practices infuse and shape a group and give them ways of embodying and inhabiting the claims that draw them together. These kinds of scholars recognize that religion, ideologies and beliefs are tied to embodiment and practice. Indeed, there has been some significant work done by Donovan Schaefer (2015) that appeals to affect theory and the emotions as a better way to understand religion in the context of science. And, Harvey Whitehouse and Cristine Legare are researching the scientific study of ritual which has vital import for understanding not only religion as a practice but even science as it is practiced. ${ }^{9}$

\section{Greater Dialogue with Science and Technology Studies}

Paying attention to practice in the sciences naturally leads to the third area of future engagement—with Science and Technology Studies. Science and Technology Studies (sometimes referred to as Science, Technology and Society) has been a growing field the last 50-60 years. It is an offshoot of science studies and it assesses how political, social and cultural forces affect science and technology and how science and technology, likewise, influence politics, society and culture. In other words, it studies how science and technology are endemically human disciplines and practices.

Perhaps the greatest contribution this new area of dialogue would make to the field of science and religion is its scrutiny of the big elephant in the room, technology, and the difference it makes to science and society. It is incredibly surprising to me that technology 
has been overlooked in the field for so long. Particularly because Barbour's seminal Gifford lectures includes the forgotten second volume Ethics in an Age of Technology (1992). Perhaps explanation should be sought in the title of the field itself: we are talking about "science" and religion, not "technology" and religion. Or perhaps explanation for its absence might be sought in a major tenet of the philosophy of technology: that the point of technology is that it remains tacit and seamless with our actions. By its very essence technology is meant to remain hidden and, thus, it has remained unstudied.

However, it has been absent from the conversation for far too long. We wouldn't have modern science today without technology and vice versa. It surely inflects and colors our experience of the natural world when doing science and, clearly, it does so outside of the laboratory. Furthermore, it is the most immediate way people outside of the sciences experience the fruits of science. Science and Technology Studies recognizes the power of technology in the scientific world and even gives it a new name to better describe the incorporated synthesis of both in our contemporary world - technoscience. ${ }^{10}$ There is an entire conversation happening in this field that is so close and relevant to what we do in science and religion - history of science and technology, philosophy of science and technology, hermeneutic and critical approaches to both - that it amazes me there hasn't been more interaction to date. We would have a lot to gain from this interaction.

Indeed, one area of perceived growth in the future for science and religion related to technology is in the future of human transformation. With the mapping of the human genome and new ground-breaking biotechnologies such as CRISPR/Cas9 the future of genetic engineering has really arrived. We can do it cheaply, universally and effectively now when not more than a couple decades ago we could not. Proximate ethical and safety issues always arise with these new technologies and powers but what is often overlooked are the anthropological and special implications of intentional genomic change. Right now the USA 
and Europe have banned the intentional modification of the germline (the heritable genetic material), but CRISPR was used not so long ago in China to alter the germline (Cyranoski and Reardon April 22,2015). This could initiate vast changes to the human species and has even incited many to speak about a transhuman or posthuman future that invites substantial theological reflection beyond just immediate ethical concerns. ${ }^{11}$

\section{Expanding into the Humanities}

Finally, I want to turn to the last area that science and religion should turn to as part of broadening its borders: the humanities. Charles P. Snow famously summarized in 1959 the growing rift between the sciences and the humanities in what is referred to as "The Two Cultures". Snow contended that the major hurdle to solving global problems in the $20^{\text {th }}$ century stems from this undesirable bifurcation. Indeed, it is difficult to find anyone in higher education who is not privy to the proliferation of specialization in the academy and the constant splintering of relative academic disciplines. I'm sure we wouldn't suffer so much if this splintering were not beset with diverging disciplinary cultures nor the ensuing lack of dialogue or synthesizing that fails to take place. Indeed, the very idea of a uni-versity with a common pursuit of knowledge almost seems laughable now - then again "multi-versity" sounds rather strange if not more correct.

But here the field of science and religion is in a privileged position. Science and religion can act as a vanguard for bridging these two cultures and, indeed, it has a responsibility to do so. Because the field has had such consistent dialogue and practical experience "crossing the aisle" these last 50 years, we ought to invite other disciplines into our conversation; not only because the state of education needs it, but because science and religion has much to gain from it as well. 
What is to be gained? Several things. Deepening discussions with those in literature has vast import for science and religion. A neglected topic within science and religion is the imagination and its role in the construction of controlling images, metaphors and analogies that are the bedrock of the scientific and religious task. Janet Soskice's book, Metaphor and Religious Language (1985), is a good start but it has been calling out for companion pieces the last 20-30 years. This means we pay little attention to the role of science fiction - the cradle of the scientific imagination - in influencing people's beliefs on science and religion topics. Instead, it is dismissed as half-baked science or idle speculation not worthy of academic attention. Gaining a stronger appreciation for the imagination in science and religion also means taking the literary and existential/religious category of myth seriously.

De-mythologisation might have had its place in the early $20^{\text {th }}$ century but we cannot deny the role particular narratives of the existential/mythic variety play in our lives and this influences how we perceive and pursue both science and religion together and respectively. It really is time to expand our remit and invite the rest of the humanities to the table.

\section{Conclusion}

The field of science and religion is at a crossroads. As I have indicated, much of the past dialogue has focused on the natural sciences and Christianity with important input from history and philosophy. However, we are seeing today a major transition within the field and, I have argued, requires a broadening of the boundaries. For the health of the field, what is required is no less than (1) expansion into non-Christian religions and theology; (2) more substantial discourse in the human sciences; (3) greater dialogue with the burgeoning field of Science and Technology Studies and (4) broadening into the humanities more generally. As we meet the present opportunities and challenges we currently face, it is imperative we 
respond to them well. And, perhaps in another half century our own academic progeny will

be assessing how well we both diagnosed the field and acted for the betterment of it.

\footnotetext{
${ }^{1}$ And a deistic God who is "necessary" for the world's continuity and coherence is bound to be removed. See Eberhard Jüngel (1983) for a genealogy of the removal of a necessary God in public life.

${ }^{2}$ See David Livingstone (2014) for a wonderful assessment "place, politics and rhetoric" played in the reception of Darwinian evolution in unique geographical, cultural and religious settings.

${ }^{3}$ Barbour also cites the work of Charles Coulson (1955).

${ }^{4}$ Notable texts that are the exception and represent science and religion in the non-Christian faiths include: Bruce Alan Wallace (2003), Noah Efron (2007) and Ahmad Dallal (2010). Indeed, I laud the editorial staff at Zygon for their initiative in 2015 to intentionally extend this discussion globally and into other faiths around the world (Drees 2016).

${ }^{5}$ Excellent texts that study the plurality of secularisation around the world include: Charles Taylor (2007), Peter Berger, Davie, and Fokas (2008) and Craig Calhoun, Juergensmeyer, and VanAntwerpen (2011).

${ }^{6}$ Taede Smedes $(2008,244 \mathrm{ff})$ makes the same point where he reflects on the lack of real impact the field of science and religion has made on the core of theology.

${ }^{7}$ Whilst James K. Smith and Amos Yong acknowledge exactly the need to address science and religion from a Pentecostal and Renewalist position because of its spread southward, all contributions in this text are still based in the Renewalism of America and Europe. Surely this needs to be done first, but it does invite more contextual sources arising from places like Africa and South America in subsequent engagements.

${ }^{8}$ This neologism of Robert McCauley (2011,31-82) refers to those abilities that arise in normal functioning humans as part of the expected developmental process. These "universal" capacities require no explicit instruction and humans engage in them without effort and require no material input. An example of a maturationally natural capacity is language acquisition and use.

${ }^{9}$ For more on the scientific study of ritual see Robert McCauley and Lawson (2002).

10 The term "technoscience" commonly refers to both the constitutive practice of science and also the social and technological context of science. Technoscience designates that scientific knowledge is mediated by historical, social and material networks. For more on technoscience see Don Ihde and Selinger (2003) and Alfred Nordmann (2011).

${ }^{11}$ Two important and comprehensive texts to date engage religion with the claims and philosophy of transhumanism: Ronald Cole-Turner (2011) and Calvin Mercer and Trothen (2015).
} 
References

Atran, Scott. 2002. In Gods We Trust: The Evolutionary Landscape of Religion. New York: Oxford University Press.

Barbour, Ian G. 1966. Issues in Science and Religion. London: SCM Press. . 1968a. "Science and Religion Today." In Science and Religion: New Perspectives on the Dialogue, edited by Ian G. Barbour. London: SCM Press. ed. 1968b. Science and Religion: New Perspectives on the Dialogue. London: SCM Press.

1992. Ethics in an Age of Technology. London: SCM.

2001. "Science and Scientism in Huston Smith's Why Religion Matters." Zygon: Journal of Religion and Science 36 (2):207-214.

. 2008. "Taking Science Seriously without Scientism: A Response to Taede Smedes." Zygon: Journal of Religion and Science 43 (1):259-269.

Barrett, Justin L. 2004. Why Would Anyone Believe in God? Walnut Creek, CA: AltaMira Press.

Berger, Peter L., Grace Davie, and Effie Fokas. 2008. Religious America, Secular Europe?: A Theme and Variations. Aldershot: Ashgate.

Boyer, Pascal. 2001. Religion Explained: The Evolutionary Origins of Religious Thought. New York: Basic Books.

Brooke, John Hedley. 1991. Science and Religion: Some Historical Perspectives. Cambridge: Cambridge University Press.

Brooke, John Hedley, and Ronald L. Numbers. 2011. Science and Religion around the World. Oxford: Oxford University Press.

Calhoun, Craig J., Mark Juergensmeyer, and Jonathan VanAntwerpen, eds. 2011. Rethinking Secularism. Oxford: Oxford University Press.

Clayton, Philip, and Steven Knapp. 2011. The Predicament of Belief: Science, Philosophy, Faith. Oxford: Oxford University Press.

Cole-Turner, Ronald, ed. 2011. Transhumanism and Transcendence: Christian Hope in an Age of Technological Enhancement. Washington, DC: Georgetown University Press.

Coulson, Charles A. 1955. Science and Christian Belief. Chapel Hill: University of North Carolina Press.

Cyranoski, David, and Sara Reardon. April 22, 2015. Chinese Scientists Genetically Modify Human Embryos. Nature.

Dallal, Ahmad. 2010. Islam, Science, and the Challenge of History. New Haven, Conn: Yale University Press.

De Cruz, Helen, and Johan De Smedt. 2015. A Natural History of Natural Theology: The Cognitive Science of Theology and Philosophy of Religion. Cambridge, MA: The MIT Press.

Drees, Willem B. 2016. "Far Away and at Home: Multiple Interactions of Religion and Science." Zygon: Journal of Religion and Science 51 (2):233-238.

Ecklund, Elaine Howard. 2010. Science Vs. Religion: What Scientists Really Think. Oxford: Oxford University Press.

Efron, Noah. 2007. Judaism and Science: A Historical Introduction. Westport, Conn: Greenwood Press.

Gould, Stephen Jay. 1999. Rocks of Ages: Science and Religion in the Fullness of Life. New York: Ballantine.

Guthrie, Stewart. 1995. Faces in the Clouds: A New Theory of Religion. Oxford: Oxford University Press.

Hanson, N. Russell. 1958. Patterns of Discovery: An Inquiry into the Conceptual Foundations of Science. Cambridge: Cambridge University Press. 
Harrison, Peter. 2015. The Territories of Science and Religion. Chicago: The University of Chicago Press.

Hill, Jonathan P. 2014. "Rejecting Evolution: The Role of Religion, Education, and Social Networks." Journal for the Scientific Study of Religion 53 (3):575-594.

Ihde, Don, and Evan Selinger, eds. 2003. Chasing Technoscience: Matrix for Materiality. Bloomington: Indiana University Press.

Jenkins, Philip. 2002. The Next Christendom: The Coming of Global Christianity. Oxford: Oxford University Press.

Jüngel, Eberhard. 1983. God as the Mystery of the World: On the Foundation of the Theology of the Crucified One in the Dispute between Theism and Atheism. Translated by Darrell L. Guder. Edinburgh: T \& T Clark.

Kuhn, Thomas S. 1970. The Structure of Scientific Revolutions. 2nd ed. Chicago: University of Chicago Press.

Livingstone, David N. 2014. Dealing with Darwin: Place, Politics, and Rhetoric in Religious Engagements with Evolution. Baltimore: Johns Hopkins University Press.

McCauley, Robert N. 2011. Why Religion Is Natural and Science Is Not. New York: Oxford University Press.

McCauley, Robert N., and E. Thomas Lawson, eds. 2002. Bringing Ritual to Mind: Psychological Foundations of Cultural Forms. Cambridge: Cambridge University Press.

McGrath, Alister E. 2008. The Open Secret: A New Vision for Natural Theology. Oxford: Blackwell.

McMullin, Ernan. 1992. The Inference That Makes Science. Milwaukee: Marquette University Press.

Mercer, Calvin, and Tracy Trothen, eds. 2015. Religion and Transhumanism: The Unknown Future of Human Enhancement. Santa Barbara: Praeger.

Nordmann, Alfred. 2011. "Science in the Context of Technology." In Science in the Context of Application, edited by Martin Carrier and Alfred Nordmann. London: Springer.

Numbers, Ronald L., ed. 2009. Galileo Goes to Jail and Other Myths About Science and Religion. London: Harvard University Press.

Pew Research Center. 2011. "Global Christianity: A Report on the Size and Distribution of the World's Christian Population." http://www.pewforum.org/files/2011/12/Christianity-fullreport-web.pdf (accessed August 24, 2016).

. 2012. "“Nones" on the Rise: One-in-Five Adults Have No Religious Affiliation." http://www.pewforum.org/files/2012/10/NonesOnTheRise-full.pdf (accessed August 24, 2016).

. 2015. "The Future of World Religions: Population Growth Projections, 2010-2050:

Why Muslims Are Rising Fastest and the Unaffiliated Are Shrinking as a Share of the World's Population."

http://www.pewforum.org/files/2015/03/PF_15.04.02_ProjectionsFullReport.pdf (accessed August 24, 2016).

Plantinga, Alvin. 2011. Where the Conflict Really Lies: Science, Religion, and Naturalism. Oxford: Oxford University Press.

Polanyi, Michael. 1962. Personal Knowledge: Towards a Post-Critical Philosophy. London: Routledge \& Kegan Paul.

Schaefer, Donovan O. 2015. Religious Affects : Animality, Evolution, and Power.

Smedes, Taede A. 2008. "Beyond Barbour or Back to Basics? The Future of Science-andReligion and the Quest for Unity." Zygon: Journal of Religion and Science 43 (1):235-258. 
Smith, James K. A., and Amos Yong, eds. 2010. Science and the Spirit: A Pentecostal Engagement with the Sciences. Bloomington: Indiana University Press.

Snow, Charles P. 1993. The Two Cultures. Cambridge: Cambridge University Press.

Soskice, Janet Martin. 1985. Metaphor and Religious Language. Oxford: Oxford University Press.

Taylor, Charles. 2007. A Secular Age. Cambridge: Belknap Press of Harvard University Press.

Teilhard de Chardin, Pierre. 1975. The Phenomenon of Man. Translated by Bernard Wall. New York: Perennial Library.

Visala, Aku. 2011. Naturalism, Theism and the Cognitive Study of Religion: Religion Explained? Farnham: Ashgate.

Wallace, Bruce Alan, ed. 2003. Buddhism and Science: Breaking New Ground. New York: Columbia University Press.

Ward, Keith. 2008. The Big Questions in Science and Religion. West Conshohocken, PA: Templeton Foundation Press. 